\title{
Monitoring socio-environmental change for sustainable development: Developing a Multidimensional Livelihoods Index (MLI)
}

\author{
Caroline Donohue*, Eloise Biggs \\ Geography and Environment, University of Southampton, Southampton SO17 1BJ, UK
}

\section{A R T I C L E I N F O}

\section{Article history:}

Received 4 February 2015

Received in revised form 16 May 2015

Accepted 18 May 2015

Available online $\mathrm{xxx}$

\section{Keywords:}

Multidimensional Livelihoods Index (MLI)

Spatial analysis

Sustainable livelihoods

Post-2015

Rural

Socio-environmental

Nepal

\begin{abstract}
A B S T R A C T
To enable more effective monitoring of sustainable development for meeting targets of the post-2015 agenda, assessment is required at the sub-national level to better understand the spatial variation in factors which contribute to sustaining livelihoods. In this research we take Nepal as a case study; a nation consistently ranked as one of the poorest in the world. To understand how sustainable development can effectively promote livelihood diversification, we advocate that a multidimensional spatial approach is essential for monitoring social and environmental change to aid decision-making processes. To achieve this, a multidimensional index was created to spatially explore the landscape of livelihoods across rural Nepal. A methodology was developed to quantify the livelihoods asset pentagon (human-physical-socialfinancial-natural) of the Sustainable Livelihoods Framework. 23 socio-environmental indicators were selected to map the multidimensionality of livelihoods at the eco-development area unit level and produce the Multidimensional Livelihoods Index (MLI). Results indicate considerable spatial variability in the factors affecting people's livelihoods across Nepal. In general, the MLI decreases as you move north and east, reflecting changes in the topographic landscape and distance from the Kathmandu Valley Outcomes suggest an effective method for monitoring change at a sub-national level; highlighting potential locations and/or livelihood strategies for improving the targeting of resources (e.g. investment of foreign aid) to facilitate more sustainable development for the future.
\end{abstract}

๑) 2015 Elsevier Ltd. All rights reserved.

\section{Introduction}

As the 2015 target date for achieving the Millennium Development Goals (MDGs) is upon us, global thinking on development strategies and cooperation is transforming. Environmental concerns are now at the forefront of development thinking, with research into sustainable development concepts and initiatives at the centre of the United Nations' post-2015 agenda (UN ECOSOC, 2013). The Rio+20 Conference - held June 2012 - launched the creation of Sustainable Development Goals (SDGs), which integrate the three dimensions of economic growth, social justice and environmental stewardship (UNEP, 2013). In addition to building and expanding on the MDGs, the SDGs were proposed with the explicit intention that they be action-oriented and designed for effective implementation and monitoring (UN Sustainable Development Knowledge Platform). Central to this new agenda is the need for

\footnotetext{
* Corresponding author. University of Southampton, University Road, Southampton SO17 1BJ, UK.

E-mail address: caroline.l.donohue@gmail.com (C. Donohue).
}

more effective decision-support tools, which act as policy and investment guides for decision-makers and thus create direct links between conceptual frameworks and policy decisions. The heterogeneous nature of poverty and livelihoods is difficult to measure with conventional analytical tools because these do not incorporate potential driving forces that are spatial explicit, such as natural resource endowment or access to infrastructure (B. Davis, 2003). In recent years, considerable mapping projects have been carried out in numerous countries, the results of which have shown that poverty mapping is particularly beneficial at identifying intraregional patterns and environmental influences (Erenstein, Hellin, \& Chandna, 2007; Gibson et al., 2004; Jayaraman \& Srivastava, 2003; King, 2011; Nepal \& Bohara, 2009; Palmer-Jones \& Sen, 2006; Rogers, Emwanu, \& Robinson, 2006). In particular, recent livelihood mapping in Mozambique demonstrates the value of spatial analysis in identifying regional differences in climate change vulnerability (Hahn, Riederer, \& Foster, 2009). Achieving the SDG targets will require more effective monitoring of change at subnational scales, thereby improving the accountable reporting of spatial disparities which often go un-detected with the widely 
available aggregated national-level data. Where there are geographically linked factors strongly affecting people's livelihoods, there is a clear need for mapping at appropriate levels of spatial aggregation.

The oldest and most widely used approach to defining and measuring poverty is the monetary approach, which identifies poverty as a shortfall in consumption or income as defined by an established poverty threshold (Laderchi, 2000). Over the years, this interpretation has come under critical scrutiny, and the need for a multi-dimensional approach to ascertain levels of poverty has been emphasised in the literature for some time (e.g. Alkire, 2011; Anand \& Sen, 1997; Atkinson \& Bourguignon, 1982; Bourguignon \& Chakravarty, 2002; Tsui, 1995). The introduction of the Human Development Index (HDI) in 1990 by the United Nations (UNDP, 1990) marked the beginning of a shift from income-based poverty measurement towards a multi-dimensional approach. The development of the Multidimensional Poverty Index (MPI) in 2010 further incorporates additional indices to the HDI through considering both the amount and intensity of deprivation. The HDI and MPI have changed the dialogue on poverty research and policymaking, with the limited research into development and application of the latter suggesting far-reaching impacts to come (Alkire \& Roche, 2013; A. J. Duclos, Sahn, \& Younger, 2006; J.-Y. Duclos, 2011; Ferreira, 2011).

The MPI provides a method of assessing multidimensional poverty by incorporating 10 variables that reflect conditions of education, health and wellbeing (Alkire \& Santos, 2011). The index provides a comparable approach for assessing poverty at a representative scale within countries and cross-country. The simplicity and wide application of the index has led to essential multidimensional estimates of poverty for different time periods and locations using national-level datasets such as the Demographic and Health Surveys (DHS) (Alkire, Conconi, \& Roche, 2013). More recently, the Multidimensional Poverty Assessment Tool (MPAT) was developed by the International Fund for Agricultural Development (IFAD) to serve as a local-level poverty index. However, one fundamental limitation of the MPI and MPAT is their lack of environmental considerations. In many countries strong codependency exists between livelihoods and the environment, and environmental conditions can severely impact the level of poverty. Therefore, to achieve a socio-environmentally holistic appraisal for monitoring livelihoods, this research develops an index which uses concepts from the sustainable livelihoods framework to better distinguish the multiple dimensions of poverty. Similarly, this index also incorporates a consideration of social capital which addresses the importance of networks and connectedness, social exclusion and accessibility, often left out of traditional analyses. The Multidimensional Livelihoods Index (MLI) serves to identify the combination of livelihood assets which govern individual livelihood strategies, providing for a deeper portrayal of the varying nature of poverty and thereby increasing the potential for the effective targeting of sustainable development initiatives, both by the government and foreign aid investors. The application of this index is particularly useful for locations where human-environment interactions strongly influence livelihood outcomes.

The paper provides an introduction to the conceptual framework for assessing multidimensional aspects of livelihoods and provides a detailed commentary on the method development of the MLI. In addition, the paper presents the MLI within a wider decision-support framework by incorporating a climate change vulnerability assessment; this is to provide an example of how quantitative indices can be used to enable more informative decision-making. The MLI and supporting framework are applied to regions within Nepal and a critical appraisal of the results and index are provided.

\section{The sustainable livelihoods framework}

'Sustainable livelihoods' was developed as a concept in the 1990 s as a response to growing dissatisfaction with dominant development theories (Ashley \& Carney, 1999; Krantz, 2001). Consensus called for a shift from macro-readjustment policies and conventional top-down, centre-outward thinking, to considering the various factors and processes which constrain or enhance poor people's ability to make a living (Robert Chambers, 1988). The United Nation's Brundtland Report (1987) and a critique of the report by Chambers (1988) resulted in new poverty concepts, later referred to as 'Sustainable Livelihood Approaches' (Krantz, 2001). This conceptual advancement embraced a participatory approach to decision-making formulated from the idea that poverty does not simply consist of low income (i.e. a monetary threshold), but represents a multitude of dimensions, such as health and access to affordable education (Anand \& Sen, 1997; Chen \& Ravallion, 2012). It was realised that while economic growth may be a necessary precondition for poverty alleviation, the impoverished also require the capability to take advantage of such economic gains (Krantz, 2001).

The Sustainable Livelihoods Framework (SLF) is a conceptual approach aimed at improving our understanding of the livelihoods of poor people through considering the inherent complexities of poverty by assessing the different factors, constraints and opportunities which shape peoples livelihood strategies (DfID, 1999). The framework is divided into five components (Fig. 1). The vulnerability context can be understood as the external influences on livelihoods which affect peoples' asset base (Erenstein et al., 2007), which includes: shocks, such as a flood or a death in the family; trends, such as deforestation or population rise; and seasonality. An individual's ability to make a living for themselves is influenced by the diversity, amount and balance of the livelihood assets which a household can accumulate and draw upon to pursue various livelihood strategies (Farrington, Carney, Ashley, \& Turton, 1999). Assets are grouped into five broad types of capital:

- Human: Labour available to the household - its health, education and skills

- Physical: Capital created by economic production processes (e.g. buildings, irrigation canals)

- Natural: Land, water and biological resources

- Financial: Stocks of money to which the household has access (e.g. savings, credit)

- Social: Networks and connections - formal and informal

The SLF also considers how livelihood assets interact with wider transforming structures and processes, such as the influence of government or NGO policies, and institutions such as political or judicial bodies, corporations or community-based organisations. Processes refer to the everyday values, dictated by social norms, customs, class or religion (IFAD, 2001). Livelihood strategies refer to the combination of activities that individuals engage in based on their available assets (Scoones, 2009), with the assumption that individuals will adopt the strategies which best preserve and improve their asset base (Erenstein et al., 2007). Livelihood strategies and decisions are also motivated by a variety of individual, household, and community goals where social objectives often trump material factors (Bebbington, 1999a; Carr, 2013, 2014; King, 2011; Mcsweeney, 2004) Batterbury's concept of "productive bricolage" grounded in the political ecology approach appropriately describes the construction of livelihood systems which respond to local constraints and opportunities but are nested in broader structures and forces (2001). This is chiefly achieved through the diversification of household's activities and social support 


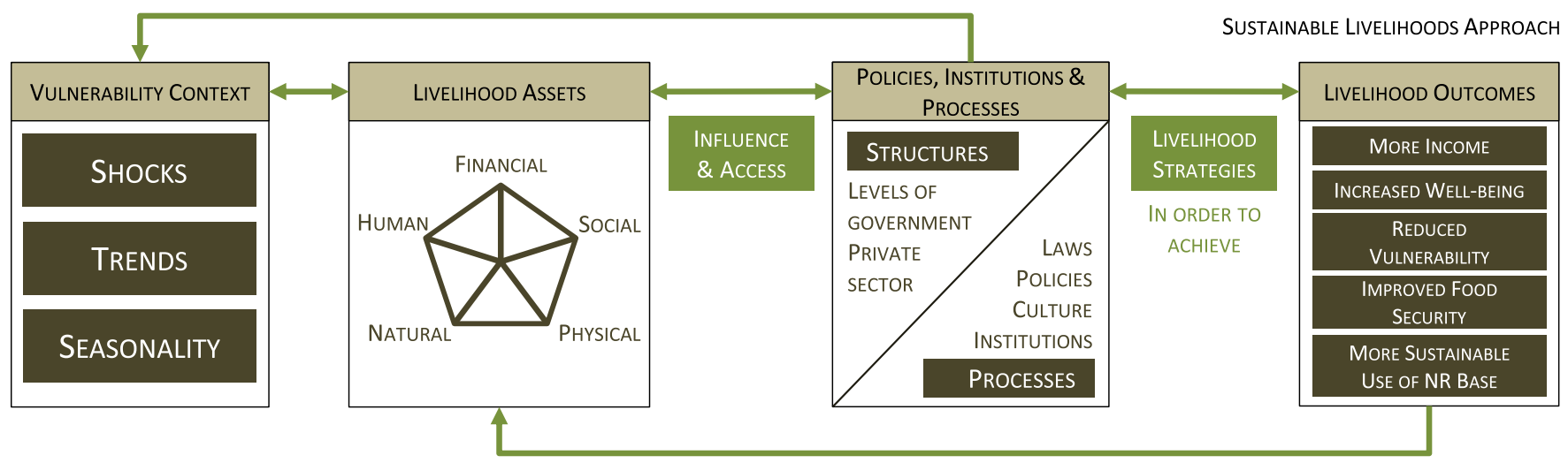

Fig. 1. Sustainable Livelihoods Framework (adapted from original DfID framework), DfID, 1999.

capabilities, and often involves reducing their reliance on natural capital assets (Batterbury, 2001). Lastly, the resulting livelihood outcome refers to the overall livelihood reality; which in turn influences future livelihood well-being, as the whole system continues in a feedback loop.

\section{The Multidimensional Livelihoods Index}

The Multidimensional Livelihood Index (MLI) was developed in this research to provide a quantitative evidence-based index to support sustainable development as a stable process for improving livelihood well-being and coping with vulnerability. While there has been considerable literature analysing the use of sustainable livelihood approaches for measuring and assessing poverty, limited research has used quantitative applications. Many projects have incorporated the SLF approach, but few have set out specifically to implement a sustainable livelihoods-based project (Neely, Sutherland, \& Johnson, 2004).

In order to maximize the usefulness of this research for policymakers and stakeholders it is important to find disaggregated data at the lowest common representative scale for generating indices. While vast amounts of data have been made public at the national level, only limited data are available at the regional or district level. In this research, the application of the MLI was conducted at the eco-development region level; the lowest representative spatial unit available for the socio-economic data used in this study. Data were standardised to ensure consistency and comparability when combining indicators. The Min-Max normalisation method was used to produce indicators with an identical range of $0-1$, which uses the following calculation:

$$
x^{1}=\frac{x-\min (x)}{\max (x)-\min (x)}
$$

where $\mathrm{x}$ is the local value of the indicator (region), min is the global minimum value of the indicator (national), and max is the global maximum value of the indicator (national). Once indicators were standardised they were combined using equal weighting. Composite scores were calculated for each livelihood capital as well as an overall composite score (MLI) which combined the capitals. Equal weighting was used due to the complexity and subjective nature of weighting livelihood indices. This assumption is acknowledged when interpreting the results and there is scope to refine the methodology for future applications using a different weighting method to create a composite index if particularly suited by the application.

\subsection{Quantifying sustainable livelihoods}

In the context of this study, the SLF is used as the overall conceptual framework, with the asset pentagon the focal point for which a multi-dimensional index was devised. As the five capitals form a holistic conceptual basis for characterising livelihoods, this component of the SLF was deemed appropriate to generate a method for quantifying livelihood assets. Twenty-three spatially explicit variables were used to represent the five livelihood capital assets (Table 1, Appendix A). Indicators were chosen based on a critical appraisal of the scientific literature available which identified those repeatedly referred to in the literature as good measures of rural people's well-being (Table 1, Appendix A). The choice of which variables to retain was made in balancing considerations of relevance with those of data quality and availability. In addition, collinearity was assessed and variables which were significantly correlated $(p<0.05)$ were left out in favour of alternates wherever possible.

\section{Application area: Nepal}

\subsection{The landscape}

Nepal is a land-locked country situated between China and India in the foothills of the Himalayas. Characterised by large geographic diversity, the country is divided into three eco-physiographic regions; mountain (Himalayas), hill (Mahabharat Range) and lowland (Terai). The mountain region is characterised by inclement climatic and rugged topographic conditions. Although a large portion of the mountain region is endowed with rich natural resources, subsistence agriculture on marginal farmland prevails, and despite a sparse and largely rural population, adverse environmental conditions have resulted in relatively high population pressure on farmland. The rural non-farm industry in Nepal has remained remarkably underdeveloped due to the considerable cost of increasing accessibility and the lack of government policies encouraging diversification and development (Bartlett, Bharati, Pant, Hosterman, \& Mccornick, 2010; Chhetry, 2009). The hill region includes the increasingly urbanised Kathmandu Valley triple cities of Kathmandu, Patan and Bhaktapur, and numerous fertile valleys; supporting nearly half of the country's population. The lowlands form the northern extension of the Indo-Gangetic plain, comprising tropical and subtropical fertile alluvial land which is intensely farmed and more remote areas covered by dense subtropical forests. $50 \%$ of the rural population resides in the lowland Terai region with great cultural diversity resulting from heavy migration from the hill districts and India (Dahal, 2003). 
Infrastructure is greatest developed in the lowlands and agricultural production is high.

\subsection{Livelihoods}

$85 \%$ of Nepal's population live in rural areas making it one of the least-urbanised countries in the world, with the rural poverty rate more than double the urban rate (Von Einsiedel, Malone, \& Pradhan, 2012). Regional disparities in the incidence of poverty indicate high rural poverty in the more remote regions in the north, far east and far west (Chhetry, 2001; ADB \& ICIMOD 2006). The majority of the rural population live at or below subsistence levels (Joshi, Maharjan, \& Piya, 2010). The heavy reliance on agriculture is further constrained by only $17 \%$ of Nepal's land being suitable for cultivation, and productivity is limited by access to irrigation facilities, with only about $24 \%$ of arable land under irrigation (Bartlett et al., 2010). While irrigation potential is high in the floodplains of the lowlands, elsewhere, agricultural growth is limited due to accessibility constraints (roads and markets) combined with geophysical restrictions. Potable water resource development has been a key component of Nepal's poverty alleviation plans, but $29 \%$ of the rural population are still lacking safe drinking water, only roughly $30 \%$ have access to proper sanitation and less than $10 \%$ have electricity (Bartlett et al. 2010; Khanal, Shrestha, \& Chimire, 2007; Pariyar, 2003; USAID n.d.). These are just some of the reasons which indicate the risky and uncertain state of livelihoods for the majority of rural Nepalis. Studies have found that the poorer the household, the less diverse their livelihood asset structure and the more precarious their income sources (Blaikie, Cameron \& Seddon, 2002; Seddon and Hussein, 2002). Rural livelihoods in Nepal are extraordinarily heterogeneous, partly due to the geographic diversity but also resulting from an over-reliance on the exploitation of local natural resources (Seddon and Hussein, 2002).

\subsection{Policy and institutions}

The Nepali government has been somewhat inefficient and ineffective at reforming the economic, health and education sectors to promote sustainable development and economic growth (Chhetry, 2001; Shakya, 2009; ADB, DFID \& ILO 2009). Poor governance, characterised by high levels of instability, weak governing capacities, over-stretched resources, and corruption in the form of clientelism and rent-seeking, continues to constrain growth and limit investment (Nepal: Critical Development Constraints, 2009). The decade-long civil war (1996-2006) has had long-lasting impacts on the social, political and economic infrastructure of the country (UNDP, 2009). This Maoist insurrection claimed more than 13,000 lives and resulted in roughly 200,000 internally displaced persons (Do \& Iyer 2006). Originating from discontent of underdevelopment and impoverishment in western parts of the country, the Maoist guerrillas took control of large sections of the rural countryside which eventually led to the abolition of the monarchy. Such civil unrest and inadequate governance have led to an acute dependence on foreign aid for most development initiatives. This has resulted in cross-cutting agendas, with the priorities of donors and aid agencies often directly conflicting with those of the Nepali government (Shakya, 2009).

\subsection{Vulnerability: shocks and trends}

Nepal's populations are exceptionally vulnerable to hydrometeorological and geophysical hazards. The mountain region is prone to heavy landslides, mudflows, and more recently Glacial Lake Outburst Floods (GLOFs) (MOAC, 2011). Landslides are frequent due to the combination of steep topography and unconsolidated geology, with high erodibility during the monsoon season. Regular flooding in the lowlands causes coarse sediment deposition, severe bank erosion, inundation and loss of soil (Kumar Pradhan, 2007; Pariyar, 2003). Nepal is also highly susceptible to seismic activity (Kumar Pradhan, 2007).

With almost $70 \%$ of the rural population entirely dependent on rain-fed subsistence agriculture, drought events can result in widespread food insecurity (Bartlett et al., 2010). The isolation of many rural communities has resulted in widespread inadequate access and storage of potable water resources during the dry season, and reduced coping capacity to water-induced hazards during the rainy season (Pariyar, 2003). Climate change could further increase the vulnerability of subsistence farmers through changes in precipitation and glacial meltwater, which could potentially increase the occurrence of extreme events and GLOFs (Agrawala et al., 2003; Alum \& Regmi, 2004; Bandyyopadhyay, 2009; Bartlett et al., 2010; IPCC, 2007); due to intricate human-environment interactions, even small fluctuations in the climate could have significant impacts on the livelihoods of the poor.

A holistic appraisal of livelihoods and sustainable development necessitates a consideration of vulnerability. Measures of poverty and well-being are all the more valuable when paired with vulnerability analyses which add a predictive component to policy and management interventions (Cannon, Twigg, \& Rowell, 2003). Identifying a region or social group's level of exposure to contingencies and stress in addition to their coping capacity allows for development planning to focus not only on poverty reduction but on long term livelihood resilience (Cannon et al., 2003; Cannon, 2008; Robert Chambers, 2006).

\subsection{Multidimensional Livelihood Index in Nepal}

The MLI was applied at the eco-development region level; regions comprised by the intersection of the country's five development regions (Eastern, Central, Western, Mid-Western and FarWestern) with the three ecological zones (Mountain, Hills and Terai). Table 1 in Appendix A lists the indicators for each capital group and describes the justification for inclusion and data sources. The reliance on data from secondary sources must be acknowledged as a possible limitation of this index, as the methods used to generate these datasets may introduce errors or inaccuracies. In addition, the methodology of this index is such that there are limitations in its direct transferability, as certain indicators are specific to livelihoods conditions in Nepal. Furthermore, given the large proportion of the population residing in rural localities and these communities being the poorest, only data classed as 'rural' were considered for this study.

MLI results for Nepal demonstrate marked spatial variation across regions. In general, the MLI decreases as you move north and east, reflecting changes in the topographic landscape and distance from the Kathmandu Valley. Fig. 2 indicates regions with the lowest scores are situated in the Mountain and Hill areas farthest from Kathmandu. The MLI ranges from 0.15 (Western Mountain) to 0.81 (Eastern Terai). The plots to the right of Fig. 2 disaggregate the MLI to represent each of the livelihood capitals. The shapes formed by the radar plots indicate that regions in the Terai have the greatest disparity between livelihood capitals, inferring that households in the Terai, on average, have access to increased livelihood asset diversity. The western regions yield particularly low capital scores with an increasing north-south gradient. The Western Mountain region in particular, has low human, physical and natural capital. The latter, while surprising given the region's abundance in water and forest resources, is indicative of the persistence of subsistence marginal agriculture and lack of development in rural non-farm industries. 


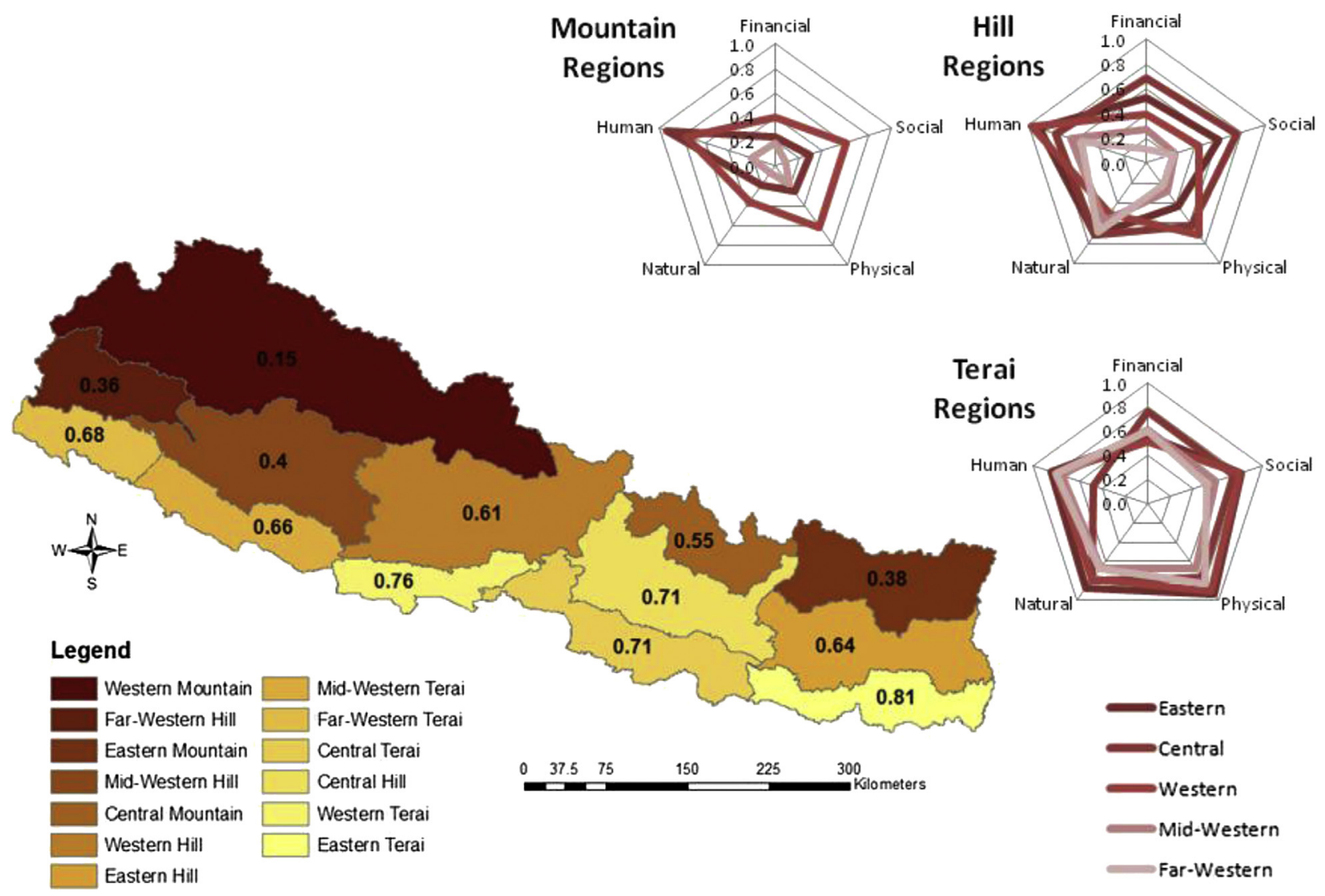

Fig. 2. MLI results for Nepal.

Natural capital scores are highest in the Terai and Eastern and Central Hill regions, reflecting the high agricultural output. Human capital scores indicate deviations from the overall index trend. The Eastern and Central Mountain regions score remarkably high, whereas low scores were found in some Hill and Terai regions. The low Central Terai score is particularly unexpected, given the beneficial agro-ecological conditions and relative proximity to the Kathmandu Valley; the high percentage of low caste groups may be one factor explaining low human capital development.

\subsection{Vulnerability to climate change}

In order to quantify the vulnerability component of the SLF, the results of a vulnerability assessment were considered in conjunction with the MLI results. Nepal's National Adaption Programme of Action (NAPA) has generated climate change vulnerability maps that assess Nepal's administrative district's vulnerability by quantifying their levels of exposure, sensitivity and adaptive capacity (NAPA, 2010). The NAPA index mirrors the widely accepted IPCC definition of vulnerability, which describes vulnerability to climate change as a function of the character, magnitude and rate of climate change exposure on a system along with its sensitivity and adaptive capacity (IPCC, 2001). Vulnerability was mapped using an index that comprises direct and proxy indicators, whereby 11 sub-indices (Fig. 3) were aggregated, averaged and normalized to a scale of 0-1 following the same Min-Max procedure as the livelihood index presented in Equation (1). The NAPA indicators and sub-indices were selected and weighted based on expert judgement and an extensive literature review as detailed in section 3.2 of the NAPA report (2010).

The resultant index values depict variations in vulnerability across Nepal, and can be used as an approach to quantify elements of the vulnerability context in the SLF. The results of the index identify several key priority areas for different types of vulnerability. Pockets of districts highly vulnerable to rainfall/temperature changes can be found across the country, especially in the mid-west hill and mountain regions and in the central region in all three physiographic zones. Flood vulnerability is quite localized in the Central Terai whereas drought vulnerability is much more widespread. Vulnerability to GLOFs is particularly acute in the Eastern and Western mountain regions. While the overall vulnerability map of Nepal is much less clear, the final NAPA results demonstrate substantial spatial differences. Fig. 4 displays the results of the three NAPA components aggregated to the eco-development region level.

The NAPA results show considerable variation in levels of sensitivity, risk and adaptive capacity across the country. Some regions, such as the Central Hill, have higher levels of sensitivity and risk but also have greater adaptive capacity for coping. The situation appears to be the reverse for the western regions-Western Mountain in particular-that have lower levels of sensitivity and risk but also lower coping capacity.

\section{Value and application of the MLI}

The development of the MLI and its application in Nepal has resulted in an increased understanding of poverty and livelihoods, adding to the field of research which emphasises the importance of considering the various determinants of poverty in a spatial context. Beyond simply representing geographic variation in livelihood well-being, such mapping provides researchers and policymakers with a better exploratory tool from which to identify 


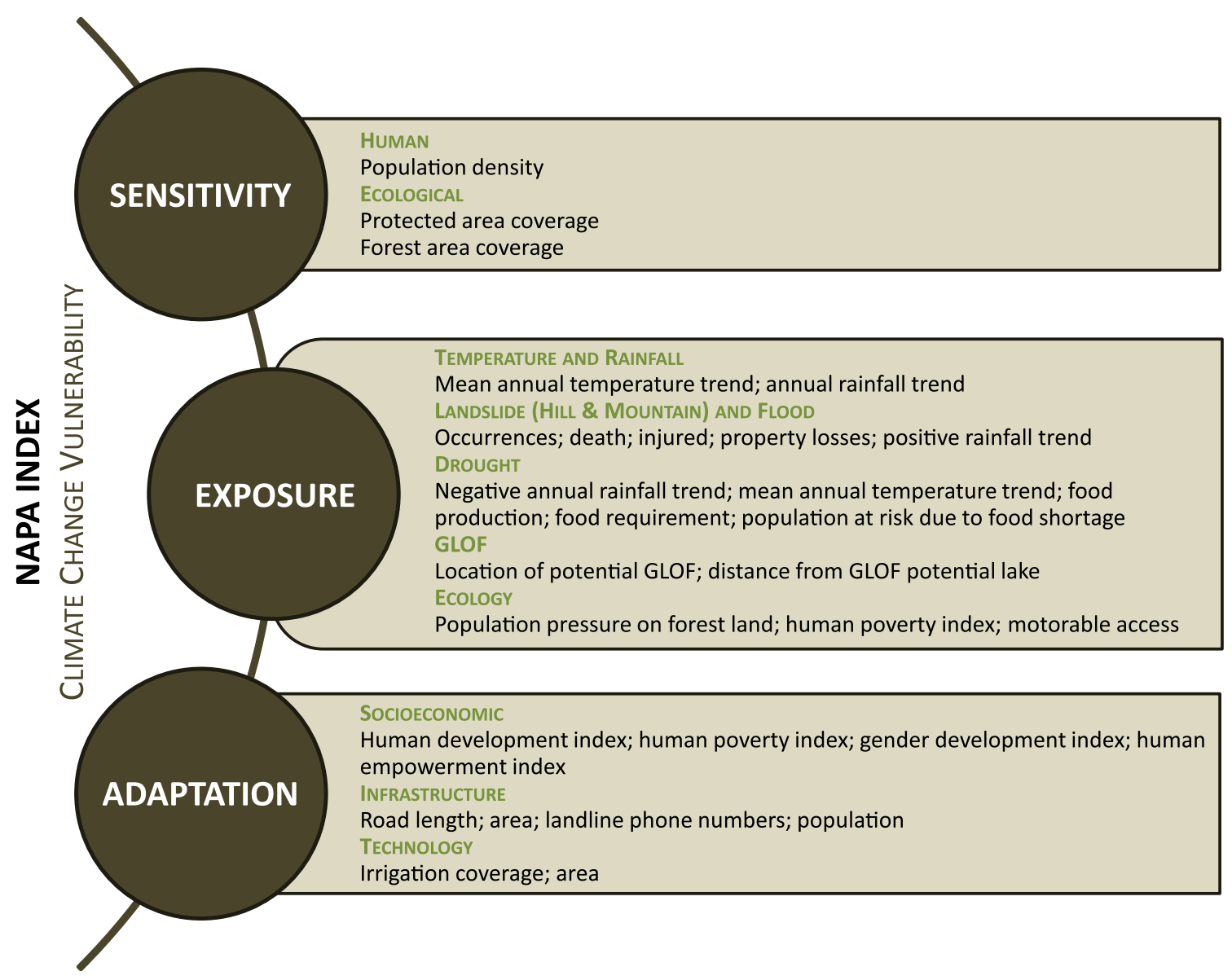

Fig. 3. NAPA vulnerability index (adapted from the NAPA climate change index 2010).

patterns of capital asset distribution, so that they can then properly identify important livelihood relationships. The value of such an approach is twofold; identifying the poor, and differentiating between poverty dimensions and poverty intensity. The MLI and wider decision support framework can assist in the better identification of relationships between capital asset access and vulnerabilities, which combined with additional research could improve our understanding of these relationships and help identify interventions. The MLI branches out from the MPI and the HDI most importantly in that it incorporates natural capital, the importance of which is increasingly emphasised in the literature (Bebbington, 1999a; Bucknall, Kraus, \& Pillai, 2000; IWR, 2012; Sherbinin, Vanwey, Mcsweeney, Henry, \& Hunter, 2008). The inherent spatial component of the MLI is valuable in and of itself, as the need to account for spatial heterogeneity in meeting the SDG targets will require substantial spatial monitoring. Additionally, the inclusion of social capital indices, although challenging to measure, adds considerable value, as the nature of civic inclusion and exclusion can have a powerful impact on an individual's livelihood wellbeing. Beyond its intrinsic value, social capital can also be drawn on to compensate for a lack of other capitals, and provide emergency relief during shock events (DfID, 1999).

Multi-dimensional livelihood mapping provides motivation for new targeting strategies and approaches. In particular, the MLI allows for a participatory approach to decision-making which seeks to address the inherent complexities of poverty by considering its multiple dimensions which often vary by location. An individual or household's asset portfolio not only governs their ability to survive or "get by", it also gives them meaning and capability to be and to act (Bebbington, 1999a; Carr, 2013). Bebbington succinctly describes assets as vehicles of instrumental action (making a living), hermeneutic action (making living meaningful) and emancipator action (challenging the structures under which one makes a living) (2001). This tool can facilitate the analysis of the relationships between capital assets within the SLF context to then provide insight for assisting with developing the appropriate policies for poverty reduction. Identifying the particular combination of livelihood assets available to impoverished households in a given region, for example, as explored for the Western Hill and Central Terai (Fig. 5), allows for a better understanding of their varying livelihood strategies. Through quantifying proportional asset access, there is potential to focus development strategies and approaches to assist poverty alleviation strategies by contemplating an increase in access to the lacking assets. Furthermore, consideration as to whether one type of capital can be substituted for another may extend the options of livelihood support.

\subsection{Multi-index approach}

Considering the MLI alongside a vulnerability index, such as the one developed by NAPA, greatly enhances application of the index to identify areas with low capital and high vulnerability, and to increase socio-environmental understanding to enable deployment of more effective policy solutions. Fig. 5 demonstrates conceptually how the MLI and NAPA indices could be used together to identify priorities for sustainable development policy investments. In this example, the contrasting index results of Nepal's Western Hill and Central Terai regions demonstrate the potential value of such 

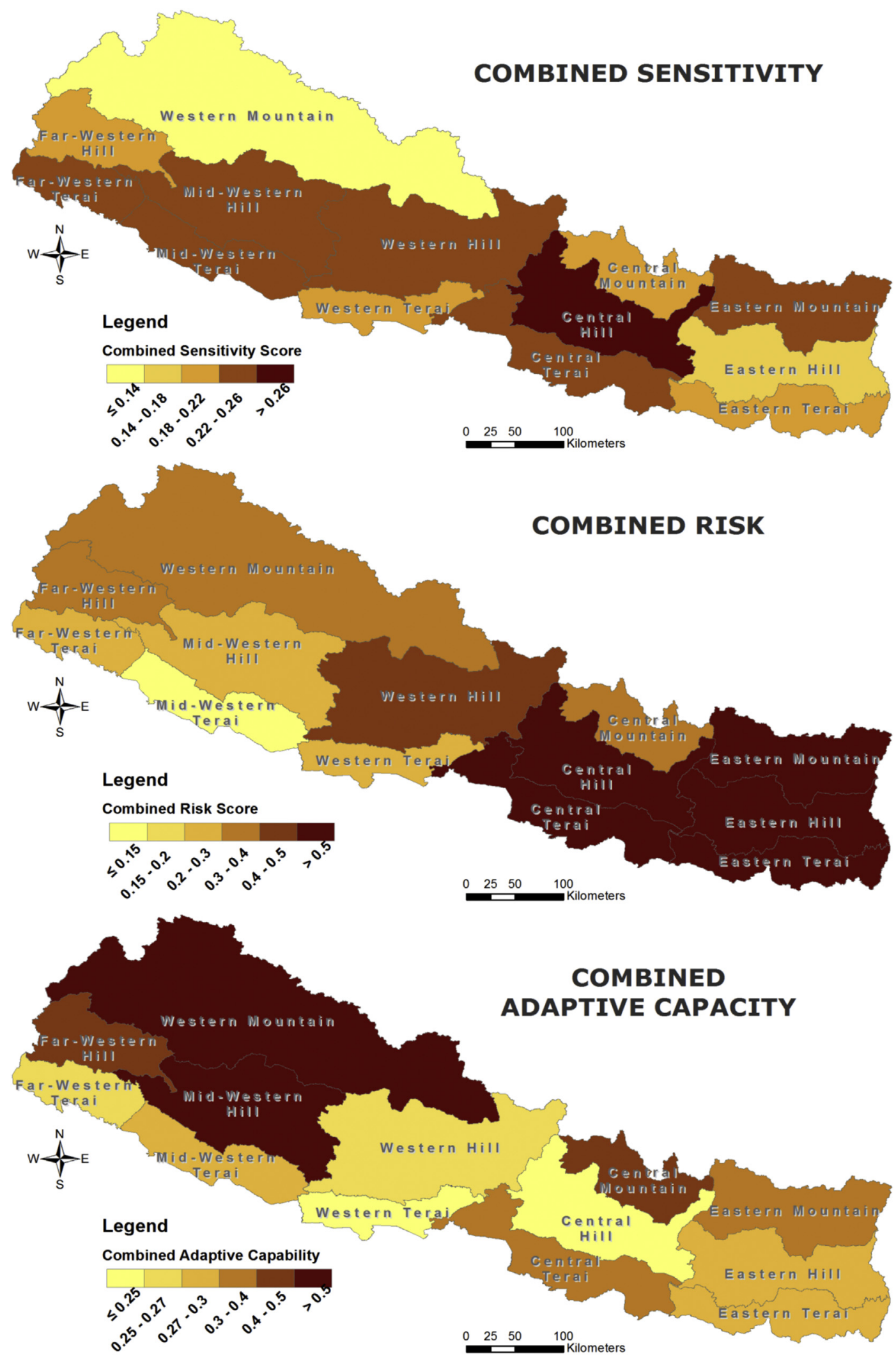

Fig. 4. NAPA results by eco-development region.

targeting. The Western Hill scores very high in human capital, followed by physical capital and relatively low scores in financial, social and natural capital. Contrastingly, the Central Terai indicates a low human capital score, despite high scores in all the other capitals. Such comparative results indicate that while poverty exists in both regions, the root causes may differ by regional average.

Greater understanding of the MLI results in both regions can be gained by considering their individual NAPA results. Fig. 5 displays 
EXAMPLE APPLICATION: INVESTMENT FOR REDUCING CLIMATE CHANGE VULNERABILITY THROUGH SUSTAINABLY ENHANCING LIVELIHOODS IN TWO ECO-DEVELOPMENT REGIONS OF NEPAL

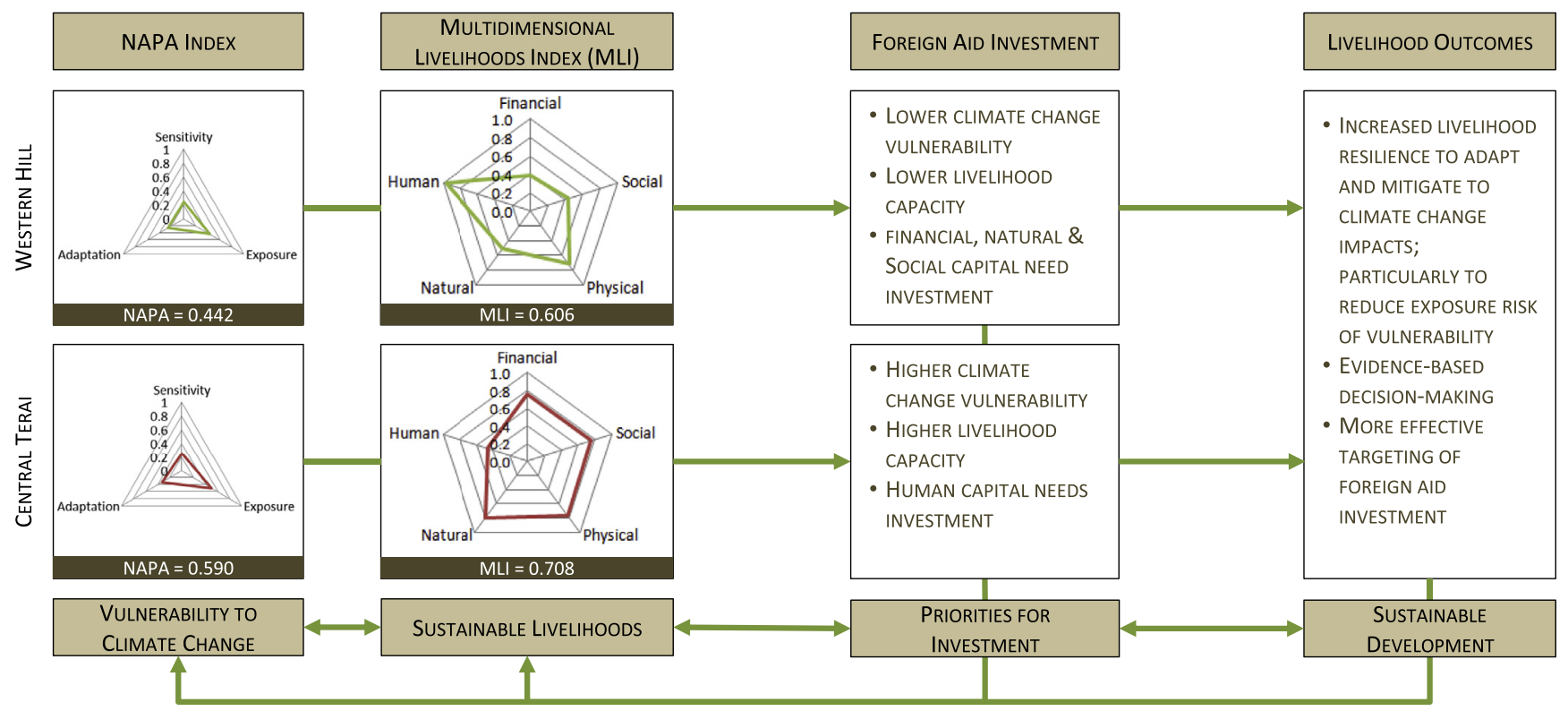

Fig. 5. SLF application in Nepal.

the overall NAPA score for each region and the different index subcomponents. The similar radar plot shapes indicate a comparable relationship between the sensitivity, adaptation capability and risk sub-indices for both regions. However, the Central Terai's slightly larger triangle illustrates the higher overall vulnerability in that region. Despite the relatively similar levels of vulnerability in both regions, Fig. 6 reveals the sources of exposure to vary between regions. Landslide and GLOF exposure in the Western Hill results in high vulnerability, whereas vulnerability is high in the Central Terai due to flooding and rainfall/temperature exposure.

The results of both indices suggest markedly different challenge areas for sustainably improving livelihoods in each region. The Central Terai's low human capital indicator scores may suggest key areas of priority which, if improved, could go a long way towards improving the adaptive capability and therefore resilience in the face of flood or drought shock events. For example, targeting female literacy, which in the rural Central Terai is low at 40\%, has been consistently identified as a key factor in reducing poverty and providing wider social benefits (Anand \& Sen, 1997; LeVine, LeVine, \& Schnell, 2001; Maddox \& Esposito, 2012; McTavish, Moore, Harper, \& Lynch, 2010; Walter, 2010). Furthermore, improving the

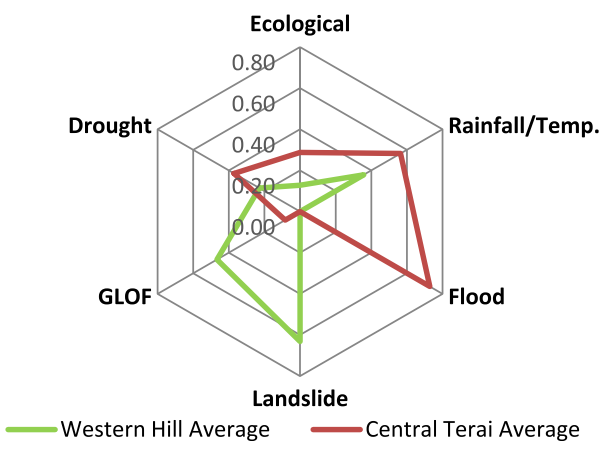

Fig. 6. NAPA risk specific vulnerability. school enrolment rate (78\%) and access to a proper basic sanitation facility (40\%) would likely drastically improve household ability to cope and plan against exposure and reduce their overall sensitivity. The recent findings of eleven empirical studies summarized by Muttarak and Lutz (2014) consistently confirm the important role of education in reducing vulnerability to climate change disasters in different settings and macro- and micro-levels. Their results demonstrate that "the protective effects of education" occur prior, during and post-disaster as higher educated individuals are better able to perceive and understand existing risks, manage and respond appropriately, and cope and rebound more quickly (Muttarak \& Lutz, 2014; Muttarak \& Pothisiri, 2013; Striessnig, Lutz, \& Patt, 2013). A study conducted in Nepal found the mean years of schooling of young people aged 15-39 to be a statistically significant explanatory variable to explain the different losses caused by landslides and floods across the country (Samir, 2013).

Conversely, the high Western Hill human and physical capital scores likely serve to counteract or, in some cases, substitute for the low natural, financial, and social capital scores. Here, as in much of Nepal, accessibility is a major constraining factor for livelihood strategies. This is evident when considering the indicator assessing access to paved roads, which in the Western Hill is an average of $3 \mathrm{~h}$. Improving road infrastructure could, for example, not only increase access to markets, and financial services, but also enable better planning for landslides and GLOFs events.

A greater understanding of the nature of poverty and improved targeting strategies has the tremendous potential for increased accountability among governments, institutions and organizations (Bedi, Coudouel, \& Simler, 2007; Henninger \& Snel, 2002). The objective, visually appealing and transparent nature of the mapped MLI results infers a powerful communication tool which can be understood amongst various stakeholders. In countries like Nepal, where corruption is high, governance is inefficient and there exists a large dependency on aid (Shakya, 2009), the MLI could strengthen transparency and promote accountability for a multi-agency approach. 


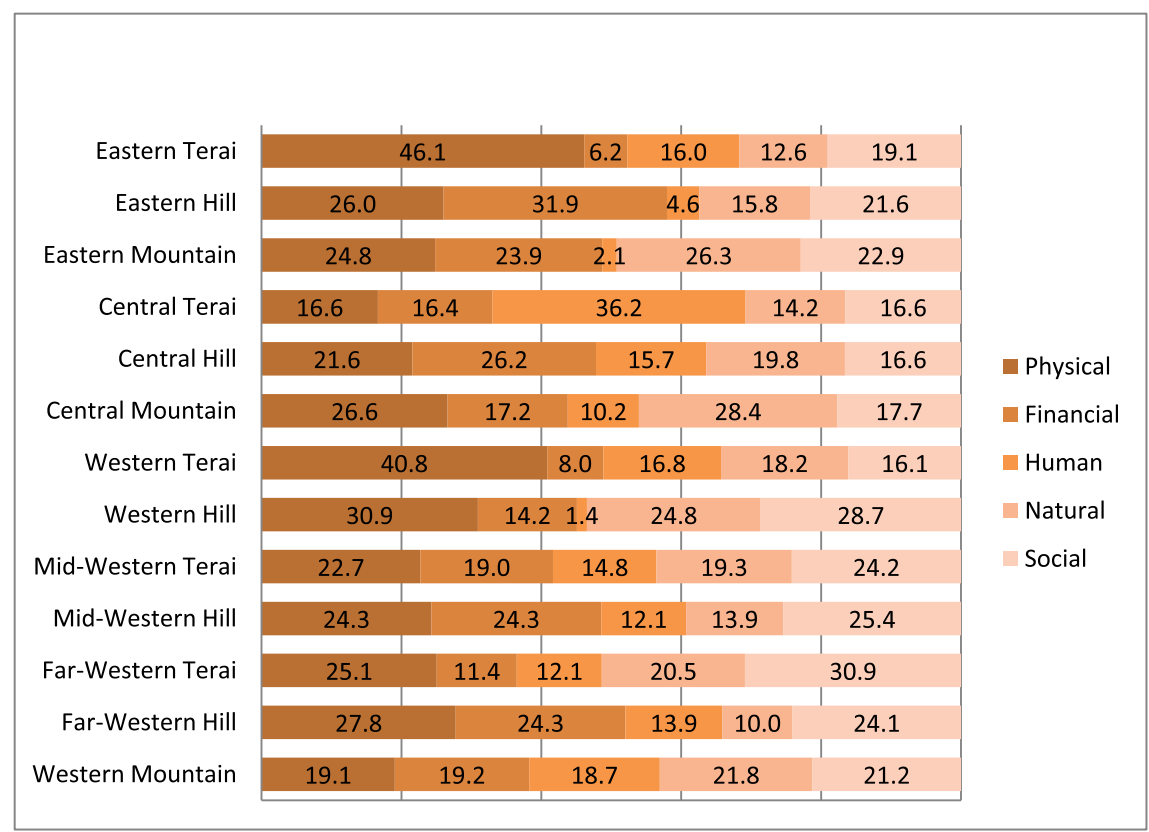

Fig. 7. \% Priority for sustainable development investment for each capital by region.

To achieve a more concrete basis for decision-making, the results of both indices can be combined. For example, the MLI and NAPA data were combined for Nepal (using Equation (2)) to highlight the capital assets where priority for development should be highest (Fig. 5). Some regions, such as the Western Mountain, have relatively equal needs across all capital asset groups. Whereas the priority areas of other regions are much more clear, such as with Physical Capital in the Western Terai and Human Capital in the Central Terai Fig. 7.

$100 * \frac{N A P A *\left(1-M L I_{x}\right)}{\sum N A P A *\left(1-M L I_{n}\right)}$

\subsection{Wider context}

The methods presented here for the MLI have the potential for application in a variety of countries. However, the selection of indicators for inclusion must be adapted according to the context. Indicators should be removed, added, or adjusted depending on the most relevant factors affecting livelihoods in a given locality. The social capital Caste indicator is an example of a country-specific indicator which was included due to the pervasive influence of the Hindu caste system in Nepal. Furthermore, the consideration of Nepal as being heavily reliant on subsistence agriculture was incorporated in the indicator decision-making process and would have to be removed or adapted to suit other contexts.

The MLI could be used to analyse livelihood well-being across space and time by incorporating time-series data. The value of a temporal analysis is evident when considering Nepal's MPI results for 2011 against those for 2006. While the overall country MPI fell from 0.35 to 0.217 , the drop in incidence of poverty $(64.7 \%-44.2 \%)$ was much greater than that of the average intensity (54\%-49\%). Considering the annualized absolute change in the individual indicators which make up the MPI reveals that Nepal experienced greater reductions in under-nutrition, electricity and assets, whereas the education and drinking water indicators improved much less substantially (Alkire, Roche, \& Seth, 2013). In this way, multi-dimensional indices which consider temporal change help policymakers to improve targeting.

Such research in conjunction with other indices within the SLF, such as a vulnerability assessment, could help identify strategies to mitigate future shocks and stresses. Indices assessing patterns in urbanisation, migrant labour patterns, or macro-economic conditions for example, can be used to quantify the first part of the SLF to allow data to be utilised to increase the effectiveness of decisionmaking for shocks, trends and seasonality which may affect livelihoods and the opportunities to build livelihood resilience. The MLI could be further refined by incorporating indicators of institutions, in order to account for the rules that regulate and constrain behaviour as well as the ways by which people make sense of their world and their place in it, as institutions differentially empower and constrain individuals (Jakimow, 2013).

\section{Concluding remarks}

The aim of this paper was to present a conceptual framework for assessing the multiple dimensions of livelihood well-being and to present the method development of the Multidimensional Livelihood Index. The use of the Sustainable livelihoods framework as the basis for the MLI has allowed for a holistic assessment of livelihood strategies. The indicators selected for inclusion provide a useful starting point from which a more rigorous methodology can be developed for different contexts. This research quantifies one component of the SLF-the asset pentagon-and thus does not operationalise the entire approach, and the quantification is entirely context-specific. Combining the MLI with measurements of vulnerability and transforming structures and processes could be particularly useful for decision-making, as demonstrated by the inclusion of a climate change vulnerability index in this application.

By assessing the multiple dimensions of livelihood well-being as well as including environmental and social concerns, the MLI is in line with current development thinking which has set sustainable development initiatives as the focus in post-Millennium Development Goal planning. The value of the MLI lies in the quantification of the asset pentagon which can provide a solid evidence-base for decision-making and can assist with development strategies within countries like Nepal in a more coherent and methodical way. The 
MLI and supporting framework were applied to regions within Nepal with the aim of demonstrating the decision-support process. Although the many limitations to this approach have restricted the direct viability and applicability of the results, the index was successful at identifying spatial variation across representative sample areas and highlighting potential key policy priority concerns. The spatially heterogeneous nature of poverty is such that effective targeting requires data at finer levels of disaggregation. Considering the varying access to forms of natural capital, in addition to the other forms of assets, is increasingly important as we begin to grasp the wide-ranging effects of climate change and improve our understanding of the complex links between the environment and human well-being.

\section{Appendix A}

Table 1

Justification of the variables selected to calculate the MLI using 23 asset indicators to represent human, physical, natural, financial and social capital.

\begin{tabular}{lll}
\hline Capital & Indicator & Variable \\
\hline Human & Female literacy & $\begin{array}{l}\text { Percentage of adult women who can } \\
\text { read and write with understanding } \\
\text { in any language }\end{array}$
\end{tabular}

Justification Data source

Child life Percentage of children born in the expectancy past five years that are still alive

School enrolment Percentage of school-aged children attending primary and lower secondary (Nepal: age $6-16$ or grades $1-10$ )

Food scarcity

Percentage of people at risk to food scarcity

Physical Safe water source

Percentage of the population having access to an improved water source

Basic sanitation Percentage of people having access to an improved sanitation facility

Electricity

Percentage of households with electricity

Access to paved roads

Travel time to closest paved road

Irrigation

Percentage of irrigated area of total cultivated land

Natural Elevation

Percentage of total area with an elevation $>3500 \mathrm{~m}$
Rural female literacy has consistently been identified as an important factor in reducing poverty (e.g. Anand \& Sen, 1997; LeVine et al., 2001; Maddox \& Esposito, 2012; McTavish et al., 2010; Walter, 2010). Maternal education in the form of literacy has been recognized as a key pathway through which women's schooling effects reproduction and health behaviour (LeVine, LeVine, Rowe, \& Schnell-Anzola, 2004). Moreover, literacy has been shown to provide wider social benefits both locally and in terms of greater social change (Gibson et al., 2004; Maddox \& Esposito, 2012), as well as being the driving transformative force crucial to the restructuring of societies (Walter, 2010) Child life expectancy is a leading indicator of the level of child health and overall development of countries (Rutstein, 2000; Sen, 1998; UNICEF, 2004; WHO, 2005). Child deaths are usually preventable, and as such, child mortality is a good gauge of malnutrition and overall healthcare (WHO, 2005)

DHS

DHS

Universal primary education has long-been a major target of poverty reduction strategies, most notably with the UN's Millennium Development Goals (MDGs; UN 2006). Education is promulgated as a principle asset in combating poverty; as a 'win-win' strategy for improving poor people's livelihoods and overall wealth creation (UNDP, 2003)

Hunger and malnutrition are some of the most wretched forms of human deprivation, as indicated by the MDG goal to halve the proportion of people suffering from extreme hunger by 2015 (United Nations Millennium Project, 2000)

The availability of safe drinking water has long been considered as vital for human well-being (Cairncross, Bartram, Cumming, \& Brocklehurst, 2010; Curtis et al. 2011; UN 2006). This is demonstrated by the MDG goal to halve the proportion of people without sustainable access to safe drinking water

The availability of basic a sanitation facility has long been considered as vital for human well-being (Cairncross et al. 2010; Curtis et al. 2011; UN 2006). This is demonstrated by the MDG goal to halve the proportion of people without sustainable access to basic sanitation

Globally, 1.5 billion people-approximately $22 \%$ of the world's population-are without access to electricity (IEA, 2009). Inadequate access is particularly acute in rural areas, where $85 \%$ of those without electricity live (IEA, 2009). Expanding access to modern energy has been identified as a necessary condition towards the economic, social and environmental aspects of human development (Byrne, Zhou, Shen, \& Hughes, 2007; IEA, 2009)

Transportation infrastructure is essential for improving access to education, health, and financial services, as well as greatly increasing the potential for agricultural growth and the development of rural nonfarm economic enterprise (Amarasinghe, Samad, \& Anputhas, 2005; J. R. Davis, 2003; Palmer-Jones \& Sen, 2006; Ulimwengu, Funes, Headey, \& You, 2009; Van de Walle, 2002). The rural poor often live in remote areas, where road development is limited as geographically difficult terrain can be challenging for improving access to basic services (Holmes \& Uphadya, 2009; Shah, 2010)

Irrigation is undoubtedly beneficial for agricultural production and has been shown to positively impact livelihoods (Brabben, Angood, Skutsch, \& Smith, 2004; R Chambers, 1987; Hussain \& Biltonen, 2001), with distinct spatial clustering of reduced rural poverty in areas of agricultural growth and irrigation development (Amarasinghe et al., 2005; Palmer-Jones \& Sen, 2006).

Exceedingly high elevations ( $>3,500 \mathrm{~m}$ ) limit agricultural land utilization due to climatic controls such as temperature, precipitation and air pressure, and such factors restrict the growth of the majority of cultivated species, as well as impede the practice of agricultural activities due to nausea and shortness of breath (Singh \& Dhillon, 2004)
NAPA/CBS

NLSS/DHS

NLSS

NLSS/DHS

NLSS

NLSS

ASTER GDEM 
Table 1 (continued)

\begin{tabular}{|c|c|c|c|c|}
\hline Capital & Indicator & Variable & Justification & Data source \\
\hline & $\begin{array}{l}\text { Distance to } \\
\text { water source }\end{array}$ & Average Euclidean distance to river & $\begin{array}{l}\text { Access to water for consumption and productive uses is a major factor in } \\
\text { rural livelihoods, especially those dominated by small-holder } \\
\text { agricultural activities (Hussain \& Giordano, 2003). Scoones (1998) } \\
\text { identifies water as a key component both in the natural capital } \\
\text { entitlements of households and of healthy ecosystems which in turn } \\
\text { provides livelihood support for millions }\end{array}$ & ICIMOD \\
\hline & Soil quality & $\begin{array}{l}\text { Percentage of 'good' soil of overall } \\
\text { land area }\end{array}$ & $\begin{array}{l}\text { In countries which are heavily reliant on agriculture, agro-ecological } \\
\text { conditions play a significant role in determining the spatial patterns of } \\
\text { rural livelihood conditions and strategies (Palmer-Jones \& Sen, 2006). } \\
\text { Soil quality is an indisputable factor determining agricultural potential } \\
\text { (Singh \& Dhillon, 2004) }\end{array}$ & SOTER 2009 \\
\hline & Precipitation & Annual average precipitation & $\begin{array}{l}\text { Precipitation is a principal factor in rural subsistence livelihoods. For } \\
\text { environments with large temporal, spatial and magnitudinal variability } \\
\text { in rainfall and runoff, precipitation can be challenging (Bartlett et al., } \\
\text { 2010). }\end{array}$ & TRMM \\
\hline & Slope & Average slope & $\begin{array}{l}\text { Topographic gradient is a main physiographic factor affecting land-use } \\
\text { and agriculture, forming restraints on cultivation and accessibility } \\
\text { (Singh \& Dhillon, 2004) }\end{array}$ & Aster GDEM \\
\hline & Cropland density & $\begin{array}{l}\text { Percentage of cropland in total land } \\
\text { area }\end{array}$ & $\begin{array}{l}\text { Land quality is of utmost importance in rural subsistence farming } \\
\text { communities. However, land arability is difficult to measure as it } \\
\text { depends on a host of environmental and physical conditions (Singh \& } \\
\text { Dhillon, 2004). For this reason the area of land under cultivation is used } \\
\text { as a proxy for arable land density, providing an indication of the general } \\
\text { potential for agriculture in each region }\end{array}$ & FAO GLC 2000 \\
\hline \multirow[t]{4}{*}{ Financial } & Value of farmland & $\begin{array}{l}\text { Total value of farmland owned by } \\
\text { the household }\end{array}$ & $\begin{array}{l}\text { Land is the most valuable asset in subsistence farming populations } \\
\text { (Bebbington, 1999b; Ellis, 2000a; Erenstein et al., 2007; Rigg, 2006), } \\
\text { serving as both a source of regular cash income through self-cultivation } \\
\text { or renting out, and as a financial reserve during shocks to the household }\end{array}$ & NLSS \\
\hline & Value of livestock & $\begin{array}{l}\text { Percentage share of small livestock } \\
\text { in overall livestock pop and the total } \\
\text { selling value of all livestock owned } \\
\text { per family }\end{array}$ & $\begin{array}{l}\text { In rural societies where there is an absence of financial markets or } \\
\text { distrust in financial institutions, savings are held in other forms (Ellis, } \\
2000 \text { b). The keeping of livestock serves an important store of wealth, } \\
\text { and during times of hardship they can be converted into other forms of } \\
\text { capital through sale or used for consumption (Dovie, Shackleton, \& } \\
\text { Witkowski, n.d.; Ellis, 2000b) }\end{array}$ & NLSS \\
\hline & $\begin{array}{l}\text { Access to financial } \\
\text { services }\end{array}$ & Travel time to bank & $\begin{array}{l}\text { Financial services stimulate economic growth and have a positive } \\
\text { impact on poor households and smaller firms in reducing inequality by } \\
\text { fairly distributing opportunities (Claessens, 2006; Serageldin \& Steeds, } \\
\text { 1996). }\end{array}$ & NLSS \\
\hline & Remittances & $\begin{array}{l}\text { Ratio of the percentage of national } \\
\text { income to the average share of } \\
\text { remittances in total household income }\end{array}$ & $\begin{array}{l}\text { Rural households are increasingly deploying their human capital across } \\
\text { locations (both domestically and internationally) and economic sectors } \\
\text { in order to increase income opportunities (Sherbinin et al., 2008; } \\
\text { Thieme \& Wyss, 2005). Remittances have been found to constitute the } \\
\text { largest source of external finance for developing countries after foreign } \\
\text { direct investment (Giuliano \& Ruiz-Arranz, 2009; Wimaladharma, } \\
\text { Pearce, \& Stanton, 2004) }\end{array}$ & NLSS \\
\hline \multirow[t]{4}{*}{ Social } & Caste & $\begin{array}{l}\text { Percentage Dalits in the total } \\
\text { population }\end{array}$ & $\begin{array}{l}\text { In countries with a complex religious, ethnic and social hierarchy, a } \\
\text { caste system can significantly impact upon livelihood-enhancing } \\
\text { opportunities. Castes are a complex form of endogamous hierarchical } \\
\text { social stratification which dominates everyday work and social } \\
\text { interactions, such as dominance in powerful government positions, } \\
\text { through to lowest ranking caste members who suffer social, economic, } \\
\text { educational, political and religious exclusion (Bennett, Ram Dahal, \& } \\
\text { Govindasamy, 2008; Bhattachan, Sunar, \& Bhattachan, 2009; Dahal, } \\
\text { 2003; Gurung, 2008) }\end{array}$ & NLSS/DHS \\
\hline & $\begin{array}{l}\text { Networks and } \\
\text { connectness }\end{array}$ & $\begin{array}{l}\text { Percentage of people having regular } \\
\text { access to a television, radio and } \\
\text { telephone (landline or mobile) }\end{array}$ & $\begin{array}{l}\text { The social resources for enhancing livelihoods often come in the form of } \\
\text { networks and connections that increase people's trust and ability to } \\
\text { work together to increase their access to wider institutions (DfID, 1999). } \\
\text { Information and communication technologies are economically, socially } \\
\text { and politically transformative in improving livelihoods through } \\
\text { connection (Cecchini \& Scott, 2003; Gerster \& Zimmermann, 2003; } \\
\text { Spence \& Smith, 2010) }\end{array}$ & NLSS/DHS \\
\hline & Population density & Rural population per $\mathrm{km}^{2}$ & $\begin{array}{l}\text { While population density can have negative impacts on livelihood well- } \\
\text { being in the form of natural resource depletion and pollution, increased } \\
\text { population density can be seen as a social asset in rural areas where } \\
\text { accessibility is key. The higher the population density the greater } \\
\text { possibility of kinship ties and access to government and community } \\
\text { services }\end{array}$ & CBS \\
\hline & $\begin{array}{l}\text { Distance to } \\
\text { regional capital }\end{array}$ & $\begin{array}{l}\text { Average cost distance to district } \\
\text { capital }\end{array}$ & $\begin{array}{l}\text { Regions are responsible for maintaining law and order through local } \\
\text { government administration. In addition to serving as the hub for } \\
\text { government services, the regional headquarter, being the largest city in } \\
\text { the region, is also the gateway through which the majority of } \\
\text { development workflows. Proximity to the regional capital has a positive } \\
\text { impact on people's access to a wide range of services and social } \\
\text { resources (Donnges, Ojha, \& Pearse, 2005) }\end{array}$ & $\begin{array}{l}\text { FAO (land cover); } \\
\text { ASTER (elevation); } \\
\text { ICIMOD (roads) }\end{array}$ \\
\hline
\end{tabular}




\section{References}

Agrawala, A., Raksakulthai, V., van Aalst, M., Larsen, P., Smith, J., \& Reynolds, J. (2003). Development and climate change in Nepal: Focus on water resources and hydropower (p. 64) (Paris).

Alkire, S. (2011). Multidimensional poverty and its discontents (No. 46) (Oxford).

Alkire, S., Conconi, A., \& Roche, J. M. (2013a). Multidimensional poverty Index 2013: Brief methodological note and results (pp. 1-15).

Alkire, S., \& Roche, J. M. (2013). How multidimensional poverty went down: Dynamics and comparisons (pp. 1-8).

Alkire, S., Roche, J. M., \& Seth, S. (2013b). Multidimensional poverty index 2013 (pp. $1-8)$

Alkire, S., \& Santos, M. E. (2011). Acute multidimensional poverty: a new index for developing countries. In German development economics conference. Berlin.

Alum, M., \& Regmi, B. (2004). Adverse impacts of climate change on development in Nepal: Intergrating adoption into policies and activities (No. 3) (p. 40) (Bangladesh).

Amarasinghe, U., Samad, M., \& Anputhas, M. (2005). Spatial clustering of rural poverty and food insecurity in Sri Lanka. Food Policy, 30(5-6), 493-509. http:// dx.doi.org/10.1016/j.foodpol.2005.09.006.

Anand, S., \& Sen, A. (1997). Concepts of human development and poverty: A multidimensional perspective.

Ashley, C., \& Carney, D. (1999). Sustainable livelihoods: Sustainable livelihoods: Lessons from early experience (pp. 1-64).

Atkinson, A. B., \& Bourguignon, F. (1982). The of comparison of multi-dimensioned distributions of economic status. Review of Economic Studies, 49(2), 183-201.

Bandyyopadhyay, J. (2009). Climate change and Hindu Kush-Himalayan water$\mathrm{s}-\mathrm{knowledge}$ gaps and priorities in adaptation. Sustainable Mountain Development, 56, 17-20.

Bartlett, R., Bharati, L., Pant, D., Hosterman, H., \& Mccornick, P. (2010). Climate change impacts and adaptation in Nepal.

Batterbury, S. (2001). Landscapes of diversity: a local political ecology of livelihood diversification in south-western Niger. Ecumene, 8(4).

Bebbington, A. (1999a). Capitals and capabilities: a framework for analyzing peasant viability, rural livelihoods and poverty. World Development, 27(12), 2021-2044. http://dx.doi.org/10.1016/S0305-750X(99)00104-7.

Bebbington, A. (1999b). Capitals and capabilities: a framework for analyzing peasant viability, rural livelihoods and poverty. World Development, 27(12), 2021-2044. http://dx.doi.org/10.1016/S0305-750X(99)00104-7.

Bedi, T., Coudouel, A., \& Simler, K. (2007). In More than a pretty picture: Using poverty maps to design better policies and interventions. Washington, DC: The World Bank.

Bennett, L., Ram Dahal, D., \& Govindasamy, P. (2008). Caste, ethnic and regional identity in Nepal: Further analysis of the 3006 Nepal demographic and health survey.

Bhattachan, K., Sunar, T., \& Bhattachan, Y. K. (2009). Caste-based discrimination in Nepal.

Blaikie, P. M., Cameron, J., \& Seddon, D. (2002). Understanding 20 years of change in West-Central Nepal: Continuity and change in lives and ideas. World development, 30(7), 1255-1270.

Bourguignon, F., \& Chakravarty, S. R. (2002). The measurement of multidimensional poverty.

Brabben, T., Angood, C. Skutsch, J., \& Smith, L. (2004). Irrigation can sustain rural livelihoods: Evidence from Bangladesh and Nepal.

Bucknall, J., Kraus, C., \& Pillai, P. (2000). Poverty and the environment.

Byrne, J., Zhou, A., Shen, B., \& Hughes, K. (2007). Evaluating the potential of smallscale renewable energy options to meet rural livelihoods needs: a GIS- and lifecycle cost-based assessment of Western China's options. Energy Policy, 35(8), 4391-4401. http://dx.doi.org/10.1016/j.enpol.2007.02.022.

Cairncross, S., Bartram, J., Cumming, O., \& Brocklehurst, C. (2010). Hygiene, sanitation, and water: what needs to be done? PLoS Medicine, 7(11), e1000365. http://dx.doi.org/10.1371/journal.pmed.1000365.

Cannon, T. (2008). Reducing people's vulnerability to natural hazards communities and resilience (No. 2008.34).

Cannon, T., Twigg, J., \& Rowell, J. (2003). Social vulnerability, sustainable livelihoods and disasters (pp. 1-63)

Carr, E. R. (2013). Livelihoods as intimate government: reframing the logic of livelihoods for development. Third World Quarterly, 34(1), 77-108. http:// dx.doi.org/10.1080/01436597.2012.755012.

Carr, E. R. (2014). From description to explanation: using the Livelihoods as Intimate Government (LIG) approach. Applied Geography, 52, 110-122. http://dx.doi.org/ 10.1016/j.apgeog.2014.04.012.

Cecchini, S., \& Scott, C. (2003). Can information and communications technology applications contribute to poverty reduction? Lessons from rural India. Information Technology for Development, 10, 73-84.

Chambers, R. (1987). Irrigation against rural poverty.

Chambers, R. (1988). Sustainable livelihoods, environment and development: Putting poor rural people first.

Chambers, R. (2006). Vulnerability, coping and policy. IDS Bulletin, 37(4).

Chen, S., \& Ravallion, M. (2012). More relatively-poor people in a less absolutely-poor world.

Chhetry, D. (2001). Understanding rural poverty in Nepal. In Defining an agenda for poverty Reduction: Proceedings of the first Asia and Pacific Forum on poverty (vol. 1, pp. 293-314)
Chhetry, D. (2009). Practices of poverty measurement and poverty profile of Nepal (Google eBook) (p. 22). DIANE Publishing. Retrieved from http://books.google. $\mathrm{com} /$ books? $\mathrm{hl}=\mathrm{en} \& \mathrm{lr}=\& \mathrm{id}=\mathrm{g} 1 \mathrm{~F} 6 \mathrm{qmBi} \_\mathrm{yMC} \& \mathrm{pgis}=1$.

Claessens, S. (2006). Access to financial services: a review of the issues and public policy objectives. The World Bank Research Observer, 21(2), 207-240. http:// dx.doi.org/10.1093/wbro/lkl004.

Curtis, V., Schmidt, W., Luby, S., Florez, R., Touré, O., \& Biran, A. (2011). Hygiene: new hopes, new horizons. The Lancet Infectious Diseases, 11(4), 312-321. http:// dx.doi.org/10.1016/S1473-3099(10)70224-3.

Dahal, D. R. (2003). Social composition of the population: caste/ethnicity and religion in NEPAL. In Population Monograph of Nepal 1 (pp. 87-135).

Davis, B. (2003a). Choosing a method for poverty mapping (pp. 1-48). Rome: Food and Agriculture Organization of the United States.

Davis, J. R. (2003b). The rural non-farm economy, livelihood and their diversification: Issues and options.

DfID. (1999). Sustainable livelihoods guidance sheets. London: U.K.

Do, Q., \& Iyer, L. (2006). Geography, poverty and conflict in Nepal.

Donnges, C., Ojha, J., \& Pearse, C. (2005). Planning in Nepal guideline.

Dovie, D. B. K., Shackleton, C. M., \& Witkowski, E. T. F.. (n.d.). Valuation of communal area livestock benefits, rural livelihoods and related policy issues. Land Use Policy, 23(3), 260-271.

Duclos, J.-Y. (2011). UNDP's multidimensional poverty index (pp. 1-19) (Quebec).

Duclos, A. J., Sahn, D. E., \& Younger, S. D. (2006). Robust multidimensional poverty comparisons. The Economic Journal, 116(514), 943-968.

Ellis, F. (2000a). A framework for livelihood analysis. In Rural livelihoods and diversity in developing countries (pp. 28-54). New York, NY: Oxford University Press.

Ellis, F. (2000b). The determinants of rural livelihood diversification in developing countries. Journal of Agricultural Economics, 51(2), 289-302. http://dx.doi.org 10.1111/j.1477-9552.2000.tb01229.x.

Erenstein, O., Hellin, J., \& Chandna, P. (2007). Livelihoods, poverty and targeting in the Indo-Gangetic plains: A spatial mapping approach (pp. 1-56).

Farrington, J., Carney, D., Ashley, C., \& Turton, C. (1999). Sustainable livelihoods in practice: Early application s of concepts in rural areas.

Ferreira, F. H. G. (2011). Poverty is multidimensional. But what are we going to do about it? The Journal of Economic Inequality, 9(3), 493-495. http://dx.doi.org 10.1007/s10888-011-9202-3.

Gerster, R., \& Zimmermann, S. (2003). Information and communication Technologies (ICTS) for poverty reduction (Berne).

Gibson, J., Datt, G., Allen, B., Hwang, V., Bourke, R. M., \& Parajuli, D. (2004). Mapping poverty in rural Papua New Guinea (pp. 1-26).

Giuliano, P., \& Ruiz-Arranz, M. (2009). Remittances, financial development, and growth. Journal of Development Economics, 90(1), 144-152. http://dx.doi.org/ 10.1016/j.jdeveco.2008.10.005.

Gurung, H. (2008). The Dalit context. Occasional Papers in Sociology and Anthropology, 9. http://dx.doi.org/10.3126/opsa.v9i0.1133.

Hahn, M. B., Riederer, A. M., \& Foster, S. O. (2009). The Livelihood Vulnerability Index: a pragmatic approach to assessing risks from climate variability and change-A case study in Mozambique. Global Environmental Change, 19(1), 74-88. http://dx.doi.org/10.1016/j.gloenvcha.2008.11.002.

Henninger, N., \& Snel, M. (2002). Where are the poor? Experiences with the development and use of poverty maps (Washington, DC).

Holmes, R., \& Uphadya, S. (2009). The role of cash transfers in post-conflict Nepal (pp. $1-40)$.

Hussain, I., \& Biltonen, E. (2001). Irrigation against rural poverty: an overview of issues and pro-poor intervention strategies in irrigated agriculture in Asia. In National Workshops on Pro-poor intervention strategies in Irrigated agriculture in Asia. Colombo, Sri Lanka.

Hussain, I., \& Giordano, M. (2003). Water and poverty Linkages.

ICIMOD. (2006). Environment assessment of Nepal: Emerging issues and challenges. IEA. (2009). World energy outlook (Paris).

IFAD. (2001). Sustainable livelihoods workshops.

IPCC. (2001). Third assessment report-working group II: Impacts, adaptation and vulnerability.

IPCC. (2007). Fourth assessment report: Climate change.

IWR. (2012). Inclusive wealth report 2012 measuring progress toward sustainability (pp. 1-370).

Jakimow, T. (2013). Unlocking the black box of institutions in livelihoods analysis: case study from Andhra Pradesh, India. Oxford Development Studies, 41(4), 493-516. http://dx.doi.org/10.1080/13600818.2013.847078.

Jayaraman, V., \& Srivastava, S. (2003). Poverty mapping and monitoring using information technology: Learning and perspectives from India (pp. 1-44).

Joshi, N. P., Maharjan, K. L., \& Piya, L. (2010). Poverty and food insecurity in Nepal: a review. Journal of International Development and Cooperation, 16(2), 1-19.

Khanal, N., Shrestha, M., \& Chimire, M. (2007). Flood hazard, risk and vulnerability in Nepal: the physical and socioeconomic environment. In Preparing for flood Disaster: Mapping and assessing Hazard in the Ratu Watershed, Nepal (pp. 1-24). ICIMOD, UNESCO.

King, B. (2011). Spatialising livelihoods: resource access and livelihood spaces in South Africa. Transactions of the Institute of British Geographers, 36(2), 297-313. http://dx.doi.org/10.1111/j.1475-5661.2010.00423.x.

Krantz, L. (2001). The sustainable livelihood approach to poverty Reduction: An introduction.

Kumar Pradhan, B. (2007). Disaster preparedness for natural hazards: Current Status in Nepal (Kathmandu). 
Laderchi, C. R. (2000). The monetary approach to poverty: A survey of concepts and methods (pp. 1-19).

LeVine, R. A., LeVine, S. E., Rowe, M. L., \& Schnell-Anzola, B. (2004). Maternal literacy and health behavior: a Nepalese case study. Social Science \& Medicine, 58(4), 863-877. http://dx.doi.org/10.1016/S0277-9536(03)00261-2.

LeVine, R. A., LeVine, S. E., \& Schnell, B. (2001). "Improve the women": mass schooling, female literacy, and worldwide social change. Harvard Educational Review, 71(1).

Maddox, B., \& Esposito, L. (December 2012). Literacy inequalities, mediation and the public good: a case study of physical proximity and social distance in Nepal. British Journal of Sociology of Education, 1-19. http://dx.doi.org/10.1080/ 01425692.2012.704722.

Mcsweeney, K. (2004). Rural livelihoods through Mosquitia: approaching systems of exchange. Annals of the Association of American Geographers, 94(3), 638-661.

McTavish, S., Moore, S., Harper, S., \& Lynch, J. (2010). National female literacy, individual socio-economic status, and maternal health care use in sub-Saharan Africa. Social Science \& Medicine (1982), 71(11), 1958-1963. http://dx.doi.org/ 10.1016/j.socscimed.2010.09.007.

MOAC. (2011). Climate change adaptation and disaster risk management in agriculture - Priority framework for action 2011-2020.

Muttarak, R., \& Lutz, W. (2014). Is education a key to reducing vulnerability to natural disasters and hence unavoidable climate change? Ecology and Society, 19(1).

Muttarak, R., \& Pothisiri, W. (2013). The role of education on disaster preparedness: case study of 2012 Indian ocean earthquakes on Thailand's Andaman coast. Ecology and Society, 18(4).

NAPA. (2010). Change vulnerability mapping for Nepal (pp. 1-84) (Kathmandu).

Neely, C., Sutherland, K., \& Johnson, J. (2004). Do sustainable livelihoods approaches have a positive impact on the rural poor? A look at twelve case studies (No. LSP 16).

Nepal, M., \& Bohara, A. (2009). Micro-level estimation and decomposition of poverty and inequality in Nepal. In Nepal: Critical development constraints (pp. 1-64) (Mandaluyong City, Philippines).

Palmer-Jones, R., \& Sen, K. (2006). It is where you are that matters: the spatial determinants of rural poverty in India. Agricultural Economics, 34(3), 229-242. http://dx.doi.org/10.1111/j.1574-0864.2006.00121.x.

Pariyar, M. P. (2003). Water and poverty linkages in mountain areas: a case study of Nepal. In Water and poverty linkages: Case studies from Nepal Pakistan and Sri Lanka (pp. 5-50). International Water Management Institute.

Rigg, J. (2006). Land, farming, livelihoods, and poverty: rethinking the links in the rural south. World Development, 34(1), 180-202. http://dx.doi.org/10.1016/ j.worlddev.2005.07.015.

Rogers, D., Emwanu, T., \& Robinson, T. (2006). Initiative poverty mapping in Uganda: An analysis using remotely sensed and other environmental data (pp. 1-60).

Rutstein, S. O. (2000). Factors associated with trends in infant and child mortality in developing countries during the 1990s. Bulletin of the World Health Organization, 78(10), 1256-1270. Retrieved from http://www.pubmedcentral.nih.gov/ articlerender.fcgi artid $=2560619 \&$ tool $=$ pmcentrez\&rendertype $=$ abstract .

Samir, K. C. (2013). Community vulnerability to floods and landslides in Nepal. Ecology and Society, 18(1).

Scoones, I. (1998). Sustainable rural livelihoods: A framework for analysis. Institute of Development Studies. No.72.

Scoones, I. (2009). Livelihoods perspectives and rural development. Journal of Peasant Studies, 36(1), 171-196. http://dx.doi.org/10.1080/03066150902820503.
Sen, A. (1998). Mortality as an indicator of economic success and failure. The Economic Journal, 108(January), 1-25.

Seddon, D., \& Hussein, K. (2002). The consequences of conflict: Livelihoods and development in Nepal. Overseas Development Institute. London (No. 185).

Serageldin, I., \& Steeds, D. R. (1996). Rural well-being - from vision to action: proceedings from the fourth annual world bank conference on environmentally sustainable development. In Fourth Annual world bank conference on environmentally.

Shah, A. (2010). Patterns of poverty in remote rural areas A case study of a forest-based region in Southern Orissa in India (London).

Shakya, S. (2009). Unleashing Nepal: Past, present, and future of the economy. Delhi: Penguin.

Sherbinin, A. De, Vanwey, L., Mcsweeney, K., Henry, S., \& Hunter, L. M. (2008). Rural household demographics, livelihoods and the environment. Global Environmental Change, 18(1), 38-53.

Singh, J., \& Dhillon, S. S. (2004). Agricultural geography (p. 492). New Delhi: Tata McGraw-Hill Education. Retrieved from http://books.google.com/books? $\mathrm{id}=\mathrm{zBo} \_$1ZJAQDAC\&pgis $=1$.

Spence, R., \& Smith, M. L. (2010). Reflection from and on the forum - ICT, development, and poverty reduction: Five emerging stories (vol. 6, pp. 11-17).

Striessnig, E., Lutz, W., \& Patt, A. G. (2013). Effects of educational attainment on climate risk vulnerability. Ecology and Society, 18(1).

Thieme, S., \& Wyss, S. (2005). Migration patterns and remittance transfer in Nepal: a case study of Sainik Basti in western Nepal. International Migration, 43(5), 59-98. http://dx.doi.org/10.1111/j.1468-2435.2005.00342.x.

Tsui, K.-Y. (1995). Multidimensional generalizations of the relative and absolute inequality indices: the Atkinson-Kolm-Sen approach. Journal of Economic Theory, $67,251-265$.

Ulimwengu, J., Funes, J., Headey, D., \& You, L. (2009). Paving the way for development: The Impact of road infrastructure on agricultural production and household wealth in the Democratic Republic of Congo (pp. 1-46).

UNDP. (1990). Human development report 1990. New York.

UNDP. (2003). Human development report 2003-millennium development goals: A compact among nations to end human poverty (New York).

UNDP. (2009). Nepal human development report 2009: State transformation and human development.

UN ECOSOC. (2013). World economic and social survey 2013: Post-2015 development strategies. Geneva.

UNEP. (2013). An integrated approach to goal-setting for sustainable development.

UNICEF. (2004). The state of the world's children (New York).

United Nations. (2006). Millennium development goals report. New York.

USAID. (n.d.). South Asia regional initiative for energy integration. Retrieved from http://www.sari-energy.org/PageFiles/Countries/Nepal_Energy_Overview.asp.

Van de Walle, D. (2002). Choosing rural road investments to help reduce poverty. World Development, 30(4), 575-589.

Von Einsiedel, S., Malone, D., \& Pradhan, S. (2012). Introduction. In Nepal in transition (pp. 1-33). New Delhi: Cambridge University Press.

Walter, P. (December 2012). Defining literacy and its consequences in the developing world. International Journal of Lifelong Education, 37-41.

WHO. (2005). The world health report 2005 make every mother and child count. Geneva.

Wimaladharma, J., Pearce, D., \& Stanton, D. (2004). Remittances: the new development finance? Small Enterprise Development Journal, 15, 12-20. 